\title{
ZNAČAJ ZAJEDNIČKIH ULAGANJA I KORPORATIVNOG UPRAVLJANJA ZA POVEĆANJE PROIZVODNJE I IZVOZA
}

\author{
Dr Slavica Ostojić \\ Visoka poslovna škola strukovnih studija „Prof. dr Radomir Bojković“ Kruševac \\ Dr Nemanja Damnjanović \\ Visoka poslovna škola strukovnih studija „Prof. dr Radomir Bojkovićc“ Kruševac \\ e-mail: dr.nemanja.damnjanovic@gmail.com
}

\section{Sažetak}

Opšta deindustrijalizacija snažno je pogodila svetsku ekonomiju, dovodeći u pitanje sam opstanak domaće industrije. Industrijska proizvodnja svakako je jedna od najzanimljivijih $i$ najperspektivnijih grana privrede, a sačuvano znanje $i$ potencijal dobar su temelj za njenu obnovu. Zajednička ulaganja predstavljaju važan faktor rasta i razvoja privrede jedne zemlje. Iskustva pokazuju da zajednička ulaganja zauzimaju značajno mesto $u$ strukturnim promenama proizvodnje, izvoza $i$ načinu poslovanja privrednih subjekata. Zajednička ulaganja utiču na povećanje efikasnosti domaće privrede i omogućavaju prelivanje znanja i tehnologije koje inostrani vlasnik prevodi u domaće preduzeće. Ova ulaganja predstavljaju partnerski odnos dva ili više preduzeća koja stvaraju poseban entitet tako što svako od učesnika doprinosi u formi kapitalai tehnologije, a radi preduzimanja određene ekonomske aktivnosti. Strani investitori direktno vezuju cenu kapitala za ocenu kvaliteta praksi korporativnog upravljanja.

\section{Abstract}

For each and every country, relations with foreign countries represent an important part of the economic activities. In the modern world, no country, regardless of their developmental potential and financial conditions, can be self-sufficient, especially in the aspects of economy and economic development. That is why we say that all countries rely on each other economically or that they are in a state of interdependence. Therefore, each country wants to use their comparative advantage in the production of certain goods and services in comparison to other countries they maintain economic relations with. These benefits manifest as using favorable conditions for their production, lower production costs, improved product quality, a higher level of applied technique and technology. This paper will show the importance of investing, i.e. investments, their impact on strengthening the national economy, the increase in imports. In order to be competitive in the global market, it is necessary to exchange knowledge and 
technology, which is also emphasized throughout the paper.

Ključne reči: uvoz, izvoz, korporativno upravljanje, ulaganje, konkurentnost.

Keywords: import, export, corporate governance, investment, production.

\section{Uvod}

Imajući u vidu zahteve koje sa sobom nosi proces globalizacije svetske privrede, potrebno je u što kraćem vremenskom periodu izabrati najbrže puteve reintegracije privrede Srbije u međunarodne ekonomske tokove čime bi, relativno uspešno, bio okončan proces transformacije nacionalne ekonomije u tržišnu, izvozno orijentisanu ekonomiju. $\mathrm{Za}$ unapređenje izvoza, neophodno je da naša preduzeća ispune uslove od kojih zavisi konkurentnost konkretnih proizvoda i usluga nekog preduzeća na svetskom tržištu. Za konkurentnost je bitno povećanje izvoza, zajednička ulaganja koja povezuju proizvodnju, distribuciju i transfer tehnologija, strane direktne investicije i praksa korporativnog upravljanja.

Predmet istraživanja jeste negativan odnos izvoza i uvoza koji svedoči o konkurentnosti naše privrede; formiranje zajedničkih preduzeća koja postaju forma povezivanja međunarodne proizvodnje i korporativno upravljanje koje omogućuje preduzećima da privuku ljudski i finansijski kapital i sebi obezbede održivi razvoj. Cilj istraživanja jeste sagledavanje faktora razvoja konkurentnosti industrije Srbije i definisanje nove koncepcije razvoja inovativne proizvodnje zasnovane na sticanju novih znanja. U prvom poglavlju razmatra se o problemima koji otežavaju izvoz i lavini uvoza koji je doveo do toga da je veliki deo domaće proizvodnje uništen. Drugo poglavlje ukazuje se na značaj zajedničkih preduzeća i čvršće povezivanje partnera preko granica. Poglavlje tri prezentira rezultate ankete koji pokazuju da je nakon privatizacije primenjen princip korporativnog upravljanja.

\section{Malaksavanje izvoza i lavina uvoza}

Malaksavanje izvoza i lavina uvoza veoma loše utiče na domaću privredu, čiji brojni delovi počinju da odumiru. [2] Ovakav odnos uvoza i izvoza, koji svedoči o nedovoljnoj konkurentnosti Srbije, povući će za sobom brojne negativne posledice koje će uticati na celokupno stanje naše privrede koje se stalno pogoršava.

Enorman uvoz doveo je do toga da je veliki deo domaće proizvodnje uništen, dok je sa druge strane vrlo skroman izvoz stvorio ogromne probleme, koji se gomilaju. Trgovinski deficit, ili suficit, pa i njihov rast ne mora biti dokaz o smanjenju ili povećanju konkurentnosti privrede jedne zemlje. Međutim, u našim uslovima relativno diverzificirane izvozne i uvozne strukture enorman rast trgovinskog deficita bez ikakve sumnje znači dokaz pada konkurentnosti Srbije. [1]

Mogli bismo se zapitati koje su najveće prepreke koje koče uspešniji plasman domaćih proizvoda na svetsko tržište. Da li je u pitanju nedovoljno znanje, neiskustvo i nepoznavanje stranih tržišta, slab kvalitet proizvoda i njihove visoke cene, ili možda nedostatak mogućnosti za finansiranje naših privrednika, teško pronalaženje partnera, nerazvijen marketing, ograničenost proizvodnih kapaciteta, neadekvatna i neatraktivna ambalaža, ili pak velika konkurencija? Verovatno sve po malo. Svakako je bitna prepreka izvozu i nepostojanje standarda kvaliteta, koji su domaćim preduzetnicima neophodni za plasman robe na strana tržišta, posebno na tržište EU.

\section{Globalizacija i zajednička ulaganja}

Opšti proces globalizacije je doveo do novih razloga za čvršće povezivanje partnera preko granica. Zbog toga zajednička preduzeća i drugi vidovi ugovornog odnosa postaju popularna forma povezivanja međunarodne proizvodnje i distribucije. Treba naglasiti da 
labava poslovna struktura u zajedničkom preduzeću doprinosi tome da se ona teško formiraju i teško održavaju u određenom vremenskom intervalu, pa imaju relativno visok procenat neuspeha. Iskustva brojnih zemalja su ipak pokazala da za uspešno delovanje zajedničkih preduzeća treba da postoji čvrsta upravljačka struktura u preduzeću.

Zemlje domaćini u praksi nastoje da postignu veći „tehnološki transfer“, zahvaljujući proširenom pristupu inostranim tržištima i jače povratne sprege sa domaćom privredom. Postavlja se pitanje - kako zajednička ulaganja mogu doprineti tom cilju? U mnogo slučajeva, međuodnosi u zajedničkim ulaganjima mogu ponuditi koristi za obe strane. Pregled istraživanja pokazuje da lokalni partneri mogu biti posebno dragoceni na planu obezbeđivanja specifičnih lokalnih znanja u pogledu domaćeg tržišta, lokalnih navika, lokalne poslovne prakse, lokalne radne prakse, lokalnih isporučilaca i lokalnih odnosa između poslovne administracije i države.

Posmatrano iz ugla lokalnog partnera, zajedničko preduzeće je moglo da bude organizacioni oblik da se strani partner potpunije zainteresuje za uspeh preduzeća, a ne samo za prodaju svojih usluga na domaćem tržištu. Strani partner je video u učešću domaćeg partnera mogućnost da se smanji rizik projekta na nekoliko načina:

- Učešće lokalnog partnera može da smanji finansijsko donatorstvo inostranog investitora i obim transfera sredstava preko granice.

- Lokalni partner bolje poznaje lokalnu poslovnu klimu, državnu politiku, ekonomske uslove, pa se na taj način mogu smanjiti poslovni rizici zajedničkog preduzeća.

- Lokalni partner može da bude od koristi da se mobilišu dodatna lokalna finansijska sredstva. [3]

Kada se izabere partner za zajednička ulaganja, međunarodni investitori traže pomoć da uđu na lokalno tržište, traže uvid u lokalnu poslovnu praksu, pomoć u pogledu lokalnog finansiranja, savete u nizu odluka, kao i čitav niz elemenata za saznanja o lokalnoj privredi, politici i kulturi. U ovim slučajevima zemlje domaćini ne moraju da nameću bilo kakav zahtev ili daju ponudu bilo koje vrste kako bi stimulisale strane investitore da prihvate formu zajedničkog ulaganja kao oblik proizvodnje. [4]

$\mathrm{U}$ isto vreme međunarodna preduzeća vagaju mogućnosti povećanja prihoda i smanjenja troškova zbog korišćenja lokalnog partnera naspram opšteg rizika, mogućih sukoba principa i transakcionih troškova koje one prihvataju kada ulaze u joint venture aranžmane.

Inostrani investitori koji nisu bili spremni da investiraju bez lokalnih partnera, po pravilu su tražili učešće međunarodnih finansijskih korporacija, kako bi smanjili sopstveni rizik i bolje upravljali zajedničkim preduzećem. Inostrani investitori su došli do saznanja da učešće međunarodnih finansijskih korporacija u zemljama u razvoju može da smanji rizik celog projekta. To se posebno odnosilo na stvaranje zajedničkih preduzeća sa državnim ili javnim preduzećima, gde je status međunarodnih finansijskih korporacija davao jaču pregovaračku poziciju prema vladama i omogućavao joj da deluje kao posrednik između interesa vlade i stranog investitora. Zbog njenog objektivnog nastupa, vlade su često prihvatale takvu ulogu ove agencije.

\subsection{Zajednička ulaganja i uslovljavanje izvoza}

Obavezno učešće domaćih preduzeća u vlasništvu nije najbolji način za penetraciju na međunarodno tržište.

Istraživanja pokazuju da su preduzeća u inostranom vlasništvu neuporedivo podobnija da učestvuju u globalnoj ili regionalnoj mreži međunarodnih preduzeća. Činjenice takođe pokazuju da je to bolji način da se pomogne domaćim isporučiocima da postanu izvoznici ostalim podružnicama iste roditeljske firme i nezavisnim spoljnim kupcima.

U celini bi se moglo zaključiti da činjenice koje se odnose na zajednička ulaganja 
pokazuju da zahtev za učešćem lokalnog partnera u vlasništvu preduzeća slabi izvozne performanse $u$ poređenju sa potpunim inostranim vlasništvom datog preduzeća. Kao što je ranije istaknuto, angažovana tehnologija $\mathrm{u}$ zajedničkim ulaganjima nije ista kao u preduzećima $\mathrm{u}$ potpunom inostranom vlasništvu, postoji briga $\mathrm{u}$ pogledu kvaliteta kontrole integrisanja lokalne proizvodnje u globalnu mrežu roditeljske firme, a i mogućnost preživljavanja takvih zajedničkih ulaganja je sasvim neizvesna.

Međutim, jedanput kad se preduzeća u potpunom inostranom vlasništvu upuste $u$ izvozne operacije, one često deluju kao katalizator koji stimuliše izvozne operacije i izvozne performanse domaćih preduzeća. Sektorska istraživanja su pokazala da preduzeća u potpunom inostranom vlasništvu, pod „nedvosmislenom kontrolom" roditeljske firme pomažu domaćim isporučiocima da se pojave na inostranom tržištu (direktno i indirektno). [5]

\subsection{Povratne veze sa domaćom industrijskom bazom}

U pogledu povratnih veza sa domaćom industrijskom bazom i jačanja domaće proizvodnje robe i usluga, istraživanja pokazuju da strani investitori prihvataju da ulaze u zajednička ulaganja samo kada žele da koriste specijalna upravljačka znanja, saznanja i pristup lokalnim izvorima finansiranja. [4]

$\mathrm{Na}$ osnovu iskustava moglo bi se reći da su zajednička ulaganja ekstenzivnija u pogledu veza sa domaćom privredom i da se više oslanjaju na domaće isporučioce nego preduzeća u potpunom inostranom vlasništvu. Nasuprot tome, preduzeća $u$ potpunom inostranom vlasništvu privlače vlasnike ostalih inostranih kompanija koje deluju u lokalnoj privredi i služe kao isporučioci za njihove sopstvene operacije.

Postavlja se pitanje koja od ovih struktura više doprinosi jačanju konkurentnosti lokalne privrede?
Postoje obimne i detaljne studije koje pokazuju da inostrani investitori imaju veći nivo ukupne produktivnosti $u$ odnosu na nivo koji postižu lokalni proizvođači. Preduzeća u kojima je veće inostrano prisustvo pokazuju viši nivo ukupne produktivnosti od preduzeća sa nižim stepenom inostranog prisustva. U ovom istraživanju nije prisutna jasna kontrola $u$ pogledu istraživanja razlika između preduzeća u potpunom inostranom vlasništvu i zajedničkih ulaganja.

Činjenica je da unapređuju produktivnost $u$ specifičnim industrijskim granama u kojima su locirana, preduzeća u potpunom inostranom vlasništvu izgleda dinamičnije deluju na povratne efekte integracije domaćih isporučilaca $u$ istu ili ostale industrijske grane.

\subsection{Zajednička ulaganja i transfer tehnologija}

Najveći obim transfera tehnologija između nacija odvija se u okviru razmene tehnologije između preduzeća multinacionalnih kompanija. Prilikom merenja brzine uvođenja nove tehnologije došlo se do zaključka da roditeljske firme transferišu tehnologiju svojim podružnicama $\mathrm{u}$ inostranstvu (zemljama $\mathrm{u}$ razvoju) $\mathrm{u}$ potpunom vlasništvu za jednu trećinu brže u proseku, nego što je to slučaj kod zajedničkih ulaganja ili licenci.

Istražujući efekte uslovljavanja tehnologije, došlo se do zaključka da nametanje određenih ograničenja zemlje domaćina na ponašanje inostranih preduzeća ima negativne efekte na priliv tehnologije $u$ zemlju domaćina. Nasuprot ograničenjima, najjači podsticaj za porast uvoza tehnologije $\mathrm{u}$ inostrana preduzeća potiče od rastućih konkurentskih pritisaka unutar industrijske grane u kojoj su locirane multinacionalne kompanije.

Značaj i moć rivalstva na lokalnom tržištu na planu podsticanja inostranih preduzeća da usvoje najsavremeniju tehnologiju, prvi put je dokumentovana na ponašanju preduzeća $u$ meksičkoj industriji. [6] 


\subsection{Strane direktne investicije i domaći sadržaj proizvodnje}

Vlade zemalja korisnika stranih direktnih investicija pokušavaju da nametnu zahtev domaćeg sadržaja preduzećima inostranih investitora prilikom ovog investiranja, kako bi povećali ,industrijsku povezanost“ i multiplikovali ,povratne veze“, sa namerom da se stvori konkurentna domaća industrijska struktura. Ove zemlje često ističu argument nedovoljne razvijenosti industrijskih grana kao razlog za ove zahteve, a povremeno se iznose argumenti strateške trgovinske politike. U skoro svim slučajevima, zahtev domaćeg sadržaja je praćen određenim uvoznim ograničenjima. Uprkos činjenici da je Svetska trgovinska organizacija obavezala zemlje članice da postepeno isključe iz primene zahtev domaćeg sadržaja za inostrane investicije, brzina otklanjanja ovog ograničenja i transparentnost su još uvek nedovoljno poznati i predstavljaju kontraverzno područije.

Empirijske činjenice o doprinosu zahteva „domaćeg sadržaja“ ekonomskom razvoju zemalja domaćina koje su ga usvojile, bez obzira na ciljeve istraživanja, dovode do isključivo negativnih ocena.

Zahtev za domaćim sadržajem ima nepovoljan efekat ne samo zbog toga što tržišta rada i kapitala u zemljama domaćina među zemljama u razvoju i privredama $u$ tranziciji, sama po sebi već dobro funkcionišu, već zbog toga što pokušaj „unapređenja“ funkcionisanja tržišta putem nametanja zahteva domaćeg sadržaja za inostrane firme generiše tehničke, ekonomske, upravljačke i političkoekonomske probleme za investitore i za zemlju domaćina. Ovi problemi se prepliću i teže da deluju u pravcu neefikasnog razvoja industrije, pre nego što dovedu do novog nivoa dinamičkih znanja ili vode povećanju efikasnosti, odnosno možda ubrzavaju rast.

U isto vreme, zahtevi domaćeg sadržaja koji se odnose na lokalno preduzeće, inostrane kompanije dovode do nepovoljnih političkoekonomskih odnosa između strategije inostranog investitora i domaće prakse i otvaraju vrata za fundamentalne konflikte sa domaćim vlastima.

Inostrani investitor je podstaknut da zaštiti svoju poziciju na nivou niske proizvodnje $\mathrm{i}$ visoke profitne pozicije na malom zaštićenom tržištu. Zemlje domaćini pokušavaju da pored otvorenih poslova koriguju problem visokih troškova za buduće intervencije. Inostrana preduzeća teže višim cenama i povećanim profitima, dok domaće vlasti pokušavaju da preduzmu kontra - mere, kako bi suzbile inflaciju, monopol i ,eksploataciju“. [3]

\section{Korporativno upravljanje i odluka o investiranju}

Korporativno upravljanje je skup pravila i ponašanja koja određuju kako se upravlja preduzećima. Ta pravila omogućavaju preduzećima da privuku ljudski i finansijski kapital, da efikasno vode poslovanje i da obezbede svoj dugoročni održivi razvoj uzimajući u obzir interese vlasnika i interese drugih strana koje imaju legitimne interese $u$ poslovanju društva.

Cena kapitala zavisi od rizika koji investitori pripisuju preduzećima (što je veći rizik - to je veća cena kapitala). Rizici obuhvataju sistemski rizik koji je prisutan kod svih preduzeća na nekom tržištu i rizik specifičan za neko konkretno preduzeće. Rad na korporativnom upravljanju postaje prilika za preduzeća da na svom mikro nivou smanje ukupan iznos rizika, te tako za sebe smanje troškove finansiranja. Važno je napomenuti da velike međunarodne finansijske institucije, koje su važni investitori na tržištu Srbije od nedavno, vrše analizu kvaliteta praksi korporativnog upravljanja u srpskim preduzećima, koju tretiraju kao obavezni deo prilikom odlučivanja o investiranju. Ponekad ove institucije direktno vezuju cenu kapitala za ocenu kvaliteta praksi korporativnog upravljanja. [8]

\section{Analiza iskustva korporativnog upravljanja u Srbiji}

Ishod privatizacije ne mora nužno da znači razdvajanje funkcije vlasništva od funkcije 
upravljanja. U slučajevima kada je jedna osoba kupac preduzeća, ta osoba može istovremeno da bude $\mathrm{i}$ njegov direktor $\mathrm{i}$ vlasnik. U takvim slučajevima, problem korporativnog upravljanja se ne pojavljuje. Kod većine privatizovanih preduzeća u Srbiji, rezultat privatizacije je bila koncentracije vlasništva; prodato je $70 \%$ akcija, dok je ostalih $30 \%$ podeljeno zaposlenima i građanima. Anketa nastoji da utvrdi da li su privatizovana preduzeća kod kojih nije došlo do koncentracije vlasništva sprovela promene u vođenju preduzeća. Naime, da li je privatizacija sa sobom donela razdvajanje funkcije upravljanja od vlasništva. Rezultati jasno pokazuju da je došlo do primene principa korporativnog upravljanja.[7]

Zakon o preduzećima iz 2004. god. doneo je veliku promenu u odnosu između upravnog odbora i menadžmenta. Po prethodnom zakonu iz 1996. god, generalni direktor preduzeća je imao velika ovlašćenja, dok je upravni odbor imao samo nadzornu funkciju i malu moć da odbaci odluku generalnog diraktora. Novi zakon daje upravnom odboru pravo da postavi generalnog direktora. Podela odgovornosti između uprave preduzeća i vlasnika se čini dobro izbalansirana: $63 \%$ preduzeća je izjavilo da se upravni odbor sastoji od ljudi koji su suštinski nezavisni od menadžmenta, $21 \%$ njih je odgovorilo da to nije slučaj, $10 \%$ je odgovorilo „delimično“, a 5\% da ne zna poslednja dva odgovora se mogu uzeti kao „ne“. U 57\% preduzeća, vlasnik je taj koji ima najveći uticaj na odlučivanje, u $26 \%$ to je upravni odbor, a u $10 \%$ direktor. Direktor, međutim ima značajan uticaj na upravni odbor: $31 \%$ preduzeća je odgovorio da direktor ,praktično uvek“ utiče na odluke upravnog odbora, a $63 \%$ da se to dešava „često“. Pedeset osam procenata preduzeća ima interna pisana pravila ili akte koji rešavaju problem konflikta interesa između uprave preduzeća i vlasnika, dok $37 \%$ ne poseduje takva pravila. [7]

Ovi rezultati zaslužuju razmatranje. Iako većina preduzeća tvrdi da je upravni odbor nezavisan od menadžmenta, uticaj koji direktor ima nad odborom govori suprotno. Možda bi se odgovor na pitanje da li je upravni odbor stvarno nezavisan $\mathrm{u}$ odnosu na direktora, mogao dobiti iz činjenice da čak $57 \%$ preduzeća ne isplaćuje dividende. Ovo ukazuje na činjenicu da su uprave preduzeća mnogo uspešnije u promovisanju svojih interesa nego vlasnici.

Čini se da akcionari uglavnom imaju realnu moć u odnosu na menadžment, ali ne svi. Kako će biti objašnjeno, teško da se može reći da je interes malih akcionara zaštićen. Devedeset četiri i po procenata preduzeća je odgovorilo da akcionari imaju realnu snagu da smene direktora. Pedeset sedam procenata preduzeća je reklo da najveću moć u preduzeću ima skupština akcionara, a $26 \%$ upravni odbor. Samo $10 \%$ akcionarskih preduzeća je odgovorilo da je direktor zapravo taj koji vodi glavnu reč u preduzeću.

Imajući u vidu metod privatizacije u Srbiji nakon 2001. god, malo je verovatno da se problem zaštite malih akcionara pojavljuje $u$ dramatičnom obliku zbog toga što, kod modela prodaje, novi vlasnivi imaju mogućnost da kupe više od kontrolnog udela, što znači da oni ne bi imali jak motiv da ometaju male akcionare $u$ njihovim pokušajima da akcije prodaju nekom drugom umesto većinskom vlasniku ili direktoru. Ali baš to je i poenta ankete: ona pokušava da ustanovi da, kada se radi o slobodi malih akcionara, prepreke za prodaju akcija nisu nastale kao posledica modela prodaje koji je uveden Zakonom o privatizaciji iz 2001. god.

Neki rezultati ukazuju na to da položaj malih akcionara nije osiguran privatizacijom. U čak $58 \%$ preduzeća mali akcionari nemaju pravo da slobodno prodaju svoje akcije nekome izvan preduzeća, $10 \%$ preduzeća obaveštava svoje akcionare o aktivnostima preduzeća preko pisanih materijala, 57\% preko oglasne table u preduzeću, a samo u $26 \%$ preduzeća to je prepušteno ličnoj inicijativi akcionara. Knjiga akcionara postoji u $84 \%$ preduzeća, ali samo njih $63 \%$ akcionarima dozvoljava uvid u knjigu. Čak $21 \%$ preduzeća je odgovorio da ,akcionari imaju pravo uvida $\mathrm{u}$ knjigu, ali nisu 
zainteresovani““. Mali akcionari nisu uvek slobodni da se upoznaju sa uslovima pod kojima je preduzeće prodato; $47 \%$ ima pravo da pogleda ugovor, $26 \%$ nema, dok $21 \%$ ima to pravo, ali nisu zainteresovani. Odgovor „,nezainteresovan“ je uveden ovde kao kontrolno pitanje: najverovatnije oni koji nisu zainteresovani zapravo ne znaju da li imaju pravo ili ne. [7]

Pedeset sedam procenata preduzeća dozvoljava akcionarima da glasaju preko pisma, dok $36 \%$ to ne dozvoljava. Velika većina (84\%) je odgovorilo da akcionari koji su istovremeno zaposleni $u$ preduzeću nemaju veće pravo i privilegije od onih koji nisu, ali kod $10 \%$ preduzeća to jeste slučaj.

Korporativno upravljanje takođe podrazumeva veće zarade za one koji žele više da rade. Rezultati ovog istraživanja pokazuju da je znanje o tome kako motivisati direktora da bude efikasniji i konkurentniji - slabo. Samo 37\% preduzeća isplaćuje bonuse direktorima koji bolje rade. Velika većina $(47 \%)$ ne daje bonuse, dok $10 \%$ ne zna. Zaposleni su na neki način u boljem položaju, zato što $89 \%$ preduzeća daje bonuse za prekovremeni rad.

Sudeći po praksi isplate dividendi, korporativno upravljanje i privatna svojina se ne isplate. Anketa pokazuje da čak 57\% preduzeća ne isplaćuju $\mathrm{u}$ preduzećima $\mathrm{u}$ Srbiji, što dovodi do još jednog poraznog saznanja o korporativnom upravljanju - 55\% ispitanih preduzeća ne kotira svoje akcije na berzi.

Štrajkovi i radnički protesti su se pokazali kao jedna od najvećih smetnji u dosadašnjem toku privatizacije u Srbiji. Ovo je posebno bio slučaj sa preduzećima u kojima je sam postupak privatizacije bio neregularan. Anketa je pokušala da ispita u kojoj meri radničko nezadovoljstvo nakon privatizacije može da blokira upravljanje preduzećem. Rezultati pokazuju da je $86 \%$ zaposlenih u proseku učlanjeno u sindikat. Pedeset sedam procenata preduzeća je odgovorilo da sindikati igraju ,relativno značajnu ulogu“ u životu kompanije, $10 \%$ da igraju ,veoma važnu ulogu“, dok je $31 \%$ odgovorilo da sindikati ne igraju nikakvu ulogu u preduzeću. Čak $84 \%$ preduzeća je potpisalo kolektivni ugovor sa svojim sindikatima. Čini se da to ima uticaj na odsustvo sukoba sa sindikatima: $79 \%$ preduzeća je odgovorilo da štrajkovi i obustave rada nikada nisu pogodili radu preduzeća, a $68 \%$ da nemaju štrajkove. Većina novih vlasnika, njih $63 \%$ isplatilo je zaostale zarade nakon preuzimanja preduzeća. (U ostalih $26 \%$ slučajeva nije bilo zaostalih zarada koje je trebalo isplatiti nakon preuzimanja.) [7]

\section{Zaključak}

Enorman uvoz doveo je do toga da je veliki deo domaće proizvodnje uništen, dok je sa druge strane vrlo skroman izvoz stvorio ogromne probleme koji se gomilaju. Uvozom i izvozom roba i usluga, utiče se na regulisanje odnosa ponude $\mathrm{i}$ tražnje na domaćem tržištu. Izvozom se omogućava rast proizvodnje iznad nivoa potreba domaćeg tržišta. Odsustvo inostrane robe sa domaćeg tržišta dovodi do monopola domaćih proizvođača na njemu i rađa čitav niz ekonomskih neracionalnosti kako na tržištu tako i u proizvodnji i potrošnji. Trgovinski deficit, ili suficit, pa i njihov rast ne mora biti dokaz o smanjenju ili povećanju konkurentnosti privrede jedne zemlje. Međutim, u našim uslovima relativno diverzificirane izvozne i uvozne strukture enorman rast trgovinskog deficita bez ikakve sumnje znači dokaz pada konkurentnosti Srbije.

Razlozi za zajednička ulaganja mogu biti različiti: razvoj nove tehnologije i prodor na nova tržišta. Preduzeća se odlučuju za zajednička ulaganja zbog visokog stepena rizika i nedostatka sredstava, zbog čega nisu u mogućnosti sama ući u taj poduhvat. Zajedničko ulaganje je način za međusobno dopunjavanje, korišćenje resursa i transfera tehnologija.

Na bazi ovih iskustava moglo bi se zaključiti da bi izvozni potencijali domaćih preduzeća mogli da se povećaju merama politike koje maksimiziraju prisustvo inostranih fabrika 
koje se angažuju na izvozu zemlje domaćina. To bi se moglo ostvariti zahtevima za postojanjem zajedničkih ulaganja. Neophodno je da sa parterima iz inostranstva ulažemo u zajedničke projekte, da uvozimo tehnologiju i razvijamo proizvode koji će biti konkurentni na tržištu.

$\mathrm{Na}$ osnovu ovih činjenica $\mathrm{u}$ pogledu povratnih efekata $\mathrm{i}$ ranijih indikatora $\mathrm{o}$ bržem uvođenju tehnologije u domaću privredu, može se zaključiti - ukoliko je veća aktivnost preduzeća u potpunom inostranom vlasništvu u datoj privredi, veća je i verovatnoća za prelivanje efekata na domaća preduzeća.

Ključni element u poboljšanju ekonomske efikasnosti i rasta, kao i u povećanju poverenja investitora jeste korporativno upravljanje. Ono predstavlja skup pravila i ponašanja koja određuju kako se upravlja preduzećima. Pravila korporativnog upravljanja omogućavaju preduzećima da privuku ljudski i finansijski kapital, da efikasno vode poslovanje i obezbede svoj dugoročni održivi razvoj uzimajući u obzir interese vlasnika i interese drugih strana koje imaju legitimne interese $u$ poslovanju društva. Rezultati pokazuju da, godinu dana nakon privatizacije, korporativna kultura ulazi u temelje privatizovanih preduzeća. Dalje poboljšanje korporativnog zakonodavstva bi sigurno dovelo do daljeg poboljšanja u praksi korporativnog upravljanja.

\section{Bibliografija}

1. Kovačević M, Institut za međunarodnu politiku i privredu, Beograd, 2010.

2. Madžar Lj, Kriza, tržište i ekonomska politika, Tranzicija u Srbiji i globalna ekonomska kriza, Naučno društvo ekonomista, Beograd, 2009.

3. Kovačević R, Tranzicija i trgovinska politika, Institut za spoljnu trgovinu, Beograd, 2001.

4. Beamish, Paul W., Multintional Joint Ventures in Developing Countreies, Routledge, London, 1988.
5. Stopford, John M., and Louis T. Wells Jr., Managing the multinational enterprice, Basic Books, New York, 2008.

6. Kokko, Ari, and Magnus Blomstrom, Policies to Encourage Inflows of Technology through Foreign Multinationals, World Development 23, No. 3, March, 1995.

7. Jefferson Institute, Konkurentnost privrede Srbije“, Republika Srbija, Ministarstvo finansija, 2006.

8. Privredna komora Srbije, Nacrt kodeksa korporativnog upravljanja, 2012.god.

\section{Istorija rada:}

Rad primljen: 29.03.2013.

Prva revizija: 08.05.2013.

Druga revizija: 13.05.2013.

Prihvaćen: 26.05.2013. 